Mycologia, 105(2), 2013, pp. 357-367. DOI: 10.3852/12-088

(C) 2013 by The Mycological Society of America, Lawrence, KS 66044-8897

\title{
The phylogenetic position of Postia s.l. (Polyporales, Basidiomycota) from Patagonia, Argentina
}

\author{
M.B. Pildain \\ M. Rajchenberg ${ }^{1}$ \\ Área de Protección Forestal, Centro de Investigación y \\ Extensión Forestal Andino Patagónico, C.C. 14, 9200 \\ Esquel, Chubut, Argentina, and Consejo Nacional de \\ Investigaciones Científicas y Técnicas (CONICET), \\ Argentina
}

Abstract: We investigated the phylogenetic relationships of Postia species from Patagonia with rDNA ITS and LSU sequences, together with morphological, cultural and biological features. All species in the genus were included in a "Postia clade" irrespective of whether their spores were thin- or thick-walled. This clade is characterized by tetrapolar mating, a normal nuclear behavior, metachromatic generative hyphae and absence of fiber hyphae in culture. One subclade merged the austral taxa $P$. pelliculosa and $P$. punctata, but otherwise no distinct relationships were found regarding spore shape, spore wall thickness and geographical distribution of taxa. The austral $P$. venata and the endemic $P$. carbophila, with thinwalled basidiospores, occupied variable positions in both analyses. Postia caesia from Patagonia grouped within the $P$. caesia species complex but on a separate branch. In contrast, $P$. rennyi and $P$. balsamea from Patagonia corresponded well with strains from other geographic areas. The two austral species in Ryvardenia, $R$. cretacea and $R$. campyla, characterized by nonmetachromatic hyphae, bipolar mating and an astatocoenocytic nuclear behavior, formed an independent subclade among the dimitic genera of the "Antrodia clade", far from other Postia taxa within which they had been placed previously, supporting their inclusion in a genus of their own. Postia carbophila grouped with other Postia species and not with Postia (Rhodonia) placenta as suggested previously on the basis of morphological comparisons. Instead, the latter species grouped with taxa in the dimitic genus Amyloporia with which it shares heterocytic nuclear behavior. A separation between specimens of Postia pelliculosa and Ryvardenia cretacea from either side of the Pacific (i.e. SE Australia/New Zealand and S Argentina/S Chile) suggests they could be considered different at the species level from a phylogenetic point of view.

Submitted 20 Mar 2012; accepted for publication 3 Jul 2012.

${ }^{1}$ Corresponding author. E-mail: mrajchenberg@ciefap.org.ar
Key words: Antrodia clade, mating type, molecular phylogeny, nuclear behavior, Ryvardenia

\section{INTRODUCTION}

Brown-rot polypores that display a monomitic hyphal system with clamped generative hyphae and thin- to thick-walled basidiospores have been included mostly in the genus Postia Fr., one of the largest genera in the the Polyporales (Basidiomycota). The genus was characterized on the basis of its morphological and cultural features, mating system and nuclear behavior of the mycelium by David (1980). In brief, she neatly distinguished species in this genus (treated as Spongiporus Murrill, a taxonomic synonym) by their (i) monomitic hyphal system with clamped generative hyphae with walls that are irregularly thickened in many species when examined in $5 \% \mathrm{KOH}$ (or they display this feature in culture), and which give a positive metachromatic reaction when mounted in cresyl blue; (ii) cylindrical, allantoid to ellipsoid basidiospores with thin to slightly thickened walls; (iii) long (i.e. about 3-4 wk or more) delay of spore germination in malt extract agar in vitro, (iv) regularly simple-clamped hyphae throughout the colony and non-formation of fiber hyphae in culture; (v) tetrapolar mating system; and (vi) normal nuclear behavior of the mycelium (cf. Boidin [1971] for the definitions of nuclear behavioral types, and Rajchenberg [2011] for a review of this feature in polypores).

Most species in Postia in the past were referred to Tyromyces P. Karst. but, as shown by David (1980), that name applies to species producing a white-rot in the substrate, with basidiospores that germinate rapidly in malt extract agar (i.e. within 3-7 d) and that display an astatocoenocytic nuclear behavior. This has been widely confirmed by phylogenetic studies (Yao et al. 1999, Binder et al. 2005). Because of the large number of species that historically were included in Postia, the morphological treatment and delimitation of species has been difficult and we refer to the classical work of Lowe (1975), who used a broad genus concept for this group of species (as Tyromyces) and to Gilbertson and Ryvarden (1987) for North America, Ryvarden and Gilbertson (1993, 1994) and Bernicchia (2005) for Europe, Núñez and Ryvarden (2001) for eastern Asia and Dai (2011) for species known from China. The name Postia has not been widely accepted by taxonomists and, instead, in some 
of the above mentioned works, the name Oligoporus Bref. has been used for the same species. For a discussion on this nomenclatural issue see Donk (1960), Larsen and Lombard (1986) and Walker (1996), who support the use of Postia, and Ryvarden (1991), who supports the use of Oligoporus. The exception between these positions is the one adopted by Erkkilä and Niemelä (1986) and Renvall (1992), who proposed the use of both names: Postia for taxa with thin-walled basidiospores and Oligoporus for taxa having broadly ellipsoid to short cylindrical basidiospores with thickened, cyanophilous walls, and which have a tendency to form chlamydospores in nature and/or culture.

The morphology and biology of Postia species found in the Patagonian Andes forests of southern Argentina have been summarized by Rajchenberg (2006). Nine taxa are known, of which two are endemic ( $P$. carbophila Rajchenb. and P. minuta Rajchenb.), four are austral ( $P$. dissecta [Lév.] Rajchenb., P. pelliculosa [Berk.] Rajchenb., P. punctata Rajchenb. \& P.K. Buchanan and $P$. venata [Rajchenb. \& J.E. Wright] Rajchenb.) and three are widespread in distribution (P. balsamea [Peck] Jülich, $P$. caesia [Schard.] P. Karst. and P. rennyi [Berk. \& Broome] Rajchenb.). Several of these species possess particular morphological features that may conflict with their placement in the genus. Postia pelliculosa is one of the major wood-rotting species of several Nothofagus species in the Patagonian Andes forests and is widespread in the southern hemisphere, being recorded also from eastern Africa (Ryvarden and Johansen 1980), Cameroon (Douanla-Meli 2007), Australia (Cunningham 1965) and New Zealand (Buchanan and Hood 1992). It differs from other Postia species in having relatively thick-walled basidiospores. Postia punctata has basidiospores that are slightly thick-walled and, because of their shape and size, could be compared with species of Ryvardenia Rajchenb. (see below). Postia carbophila was compared to the morphologically similar Postia placenta (Fr.) M.J. Larsen \& Lombard, proposed as the type species for the genus Rhodonia Niemelä (Niemelä et al. 2005) based on phylogenetic research (Schigel et al. unpubl). Postia balsamea is widespread in the northern hemisphere where it is circumpolar but is rare in the southern hemisphere. It is known only from the Patagonian Andes forests of Argentina, where it decays standing Saxegothaea conspicua (Podocarpaceae) and fallen Nothofagus spp. Postia caesia is widely distributed in temperate and tropical regions worldwide and is recognized as a species complex (Yao et al. 2005) whose affinities are little known. Postia rennyi is known from Europe and Asia but is unknown from the Americas except from Patagonia. For these reasons it was interesting to validate the identity of these species with means other than morphology.

In addition to the above-mentioned species, two other austral taxa have been treated under Postia: P. campyla (Berk.) Rajchenb. and P. cretacea (Lloyd) Rajchenb. but were separated into the genus Ryvardenia Rajchenb. (Rajchenberg 1994). This genus, with Polyporus cretaceus Lloyd as the type species, is characterized by: (i) basidiomes with a dimitic hyphal system with dissepiments presenting long, terminal, thick-walled hyphae that may be considered skeletal hyphae, but which is monomitic in the context; (ii) tissues that are characterized by the presence of thickwalled, clamped generative hyphae with glossy/ refringent walls that are not metachromatic in cresyl blue and that contrast with thin-walled generative hyphae; (iii) basidiospores that are obovate, broadellipsoid to drop-shaped and thick-walled, (iv) spores that germinate in 2-4 wk after discharge on malt extract agar (known only for the type species); (v) a bipolar mating system; (vi) an astatocoenocytic nuclear behavior of the mycelium; and (vii) in culture by the generative hyphae of the advancing mycelium being simple-septate but, backwards, by forming homogeneously sclerified, clamped generative hyphae and fiber hyphae that are never irregularly thick-walled (Rajchenberg 1994, 2006).

Postia pertains to the "Antrodia clade", which includes most of the known brown rotting polypores (Hibbett and Donoghue 2001, Garcia Sandoval et al. 2011). Perhaps because it is a well circumscribed group with well delimited genera that include many taxa of pathological importance in forestry, this clade has been the focus of numerous phylogenetic studies and several genera or groups of genera have been, or are being treated regularly (Kim et al. 2001, 2003, 2005, 2007; Lindner and Banik 2008; Yu et al. 2010; Lindner et al. 2011; Rajchenberg et al. 2011; Bernicchia et al. 2012). The genus Postia, though, has rarely been the focus of this type of research and few works have been published, all dealing with a small group of species (Yao et al. 2005, Hattori et al. 2011). It is clear though from the literature that the genus is well separated from Antrodia P. Karst., from other dimitic genera in the clade such as Fomitopsis $\mathrm{P}$. Karst., Daedalea Pers., Piptoporus P. Karst. and Fibroporia Parmasto, and from other monomitic genera such as Parmastomyces Kotl. \& Pouzar and Auriporia Ryvarden. Both species in Ryvardenia, $R$. campyla and $R$. cretacea are of particular interest because they were treated in several different genera such as Piptoporus and Postia but also in the whiterotting genera Spongipellis Pat., Tyromyces and/or Grifola S.F. Gray. Because of their morphological and biological peculiarities deviating from Postia, pointed 
out above, it was deemed interesting to investigate with molecular methodologies the phylogenetic support for this southern hemisphere genus and to check its relationships within the Polyporales.

The aims of the present study were (i) to evaluate the phylogenetic relationships of Postia species found in the forests of the Patagonian Andes of Argentina, (ii) to evaluate the position of the related genus Ryvardenia, (iii) to validate the determinations of Postia taxa displaying widespread distribution vis à vis specimens from the northern hemisphere and (iv) to validate the taxonomic position of several austral or endemic Postia taxa that present peculiar morphological features.

\section{MATERIALS AND METHODS}

Strains and herbarium specimens.-Most strains studied, with their voucher specimens, are deposited at the author's institutional culture collection (CIEFAPcc) and phytopathological herbarium (CIEFAP); some are duplicates deposited elsewhere, and if so the information is indicated in the text. Herbarium designations follow Holmgren et al. (1990), and culture collection designations follow the World Federation for Culture Collection website (http:// www.wfcc.info). Strains included in this study are detailed (TABLE I).

DNA extraction and PCR conditions.-For DNA extraction, Postia and Ryvardenia species from Patagonia collections were cultured in malt peptone broth with $10 \%$ (v/v) of malt extract (Merck) and $0.1 \%(\mathrm{w} / \mathrm{v})$ Bacto peptone (Difco), $2 \mathrm{~mL}$ medium in $15 \mathrm{~mL}$ tubes. The cultures were incubated at $25 \mathrm{C}$ for $15 \mathrm{~d}$ in darkness. Total DNA was extracted with the UltraClean ${ }^{\mathrm{TM}}$ Microbial DNA Isolation Kit (MO BIO laboratories Inc., Solana Beach, California), according to the manufacturer's instructions. Herbarium specimens were examined under a dissecting microscope before extraction of DNA and cleaned with a toothbrush. Samples were ground with a mortar and pestle, extracted at $70 \mathrm{C}$ for $10 \mathrm{~min}$ in $300 \mu \mathrm{L}$ bead solution (UltraClean ${ }^{\mathrm{TM}}$ Microbial DNA Isolation Kit, MO BIO laboratories Inc., Solana Beach, California) and continued according to the above protocol indicated by the manufacturer Kit instructions. DNA quantification was performed by ultraviolet spectroscopy.

PCR products amplified in this study were nuclear ribosomal LSU (LR0R-LR5) (Vilgalys and Hester 1990) and ITS (ITS5-ITS4) (White et al. 1990) partial sequences. PCR reaction mixtures for amplification of both regions were the same as those described by Rajchenberg et al. (2011); the mixture included dNTPs $(0.25 \mathrm{mM}$ of each), $2.5 \mathrm{mM} \mathrm{MgCl} 2$; PCR buffer supplied with the polymerase enzyme; $0.1 \mu \mathrm{M}$ each primer; 100-500 ng DNA; and $1.25 \mathrm{U}$ GoTaq polymerase (Promega, Madison, Wisconsin). The final reaction volume was $50 \mu \mathrm{L}$. The PCR reactions were performed in a thermal cycler (My Cycler ${ }^{\mathrm{TM}}$, BioRad) and the conditions for ITS were: an initial denaturation at $95 \mathrm{C}$ (2 min), followed by 30 cycles of denaturation at $94 \mathrm{C}$ (1 min), primer annealing at $56 \mathrm{C}(1 \mathrm{~min})$ and elongation at $72 \mathrm{C}(1 \mathrm{~min})$, and a final elongation step was allowed at $72 \mathrm{C}(10 \mathrm{~min})$. For LSU the PCR conditions were: an initial denaturation at $95 \mathrm{C}$ ( $2 \mathrm{~min})$, followed by 35 cycles of denaturation at $94 \mathrm{C}(30 \mathrm{~s})$, primer annealing at $53 \mathrm{C}$ (1 min) and elongation at $72 \mathrm{C}(1 \mathrm{~min})$, with a final elongation step at $72 \mathrm{C}(5 \mathrm{~min})$. PCR products were separated on a $1 \%(\mathrm{w} / \mathrm{v})$ ethidium bromide-stained agarose gel, and the bands were visualized under UV illumination. The amplified fragments were purified and sequenced on an ABI 3700 automated sequencer (Perkin-Elmer, Foster City, California) at the DNA Synthesis and Sequencing Facility, Macrogen (Seoul, Korea). Sequences generated in this study were submitted to GenBank (TABLE I).

Sequence and phylogenetic analyses. - Sequence data generated in this study were manually edited with BioEdit 7.0.9.0 (Hall 1999), and additional sequences were retrieved from the GenBank nucleotide database. Two sequence datasets were analyzed for this study, one for ITS and one for LSU, which were treated separately because of lack of overlap (TABLE I).

Alignment of LSU and ITS sequence datasets were performed automatically with MEGA 4.0 (Tamura et al. 2007) and are available from TreeBASE (http://purl.org/ phylo/treebase/phylows/study/TB2:S12727). Analyses were conducted via maximum parsimony (MP) in PAUP* $4.0 \mathrm{~b} 10$ (Swofford 2002) and Bayesian inference (BI) in MrBayes 3.0B4 (Ronquist and Huelsenbeck 2003). MP analysis for both datasets were performed with gaps treated as missing characters, equal weighting of characters and transformations, heuristic searches with random addition of sequences (1000 replicates), TBR (tree bisection reconnection) branch swapping and MAXTREEs was set to autoincrease. A bootstrap analysis was performed with 1000 replicates with simple stepwise addition of sequences. The GTR $+\mathrm{I}+\mathrm{G}$ and $\mathrm{TVM}+\mathrm{I}+\mathrm{G}$ models of evolution were identified with Modeltest 3.7 (Posada and Crandall 1998) under selection AIC for the LSU and ITS sequence datasets respectively. BI posterior probabilities for both datasets were conducted with the suggested nucleotide evolution models for $10^{7}$ generations, by running four chains with 100000 generations using the program default priors on model parameters. Trees were rooted with Antrodiella semisupina (Berk. \& M.A. Curtis) Ryvarden and Bjerkandera adusta (Willd.) P. Karst.

Species of Fomitopsis, Daedalea, Oligoporus, Amyloporia Singer, Antrodia, Neolentiporus Rajchenb. and Postia (Rhodonia) placenta were included in the analyses because they have been associated with Postia taxa in other phylogenetic studies (Hibbett and Donoghue 2001, Kim et al. 2001, Wu et al. 2004, Yu et al. 2010). LSU sequences for Postia placenta were not available; therefore results for this species were obtained only for the ITS analysis. Similarly, material of $A$. nothofaginea and $P$. rennyi from Patagonia could not be obtained and were excluded from the LSU analysis.

\section{RESUlts}

The phylogenetic relationships of Postia and Ryvardenia species from Patagonia were estimated with two 
TABLE I. Specimens presented in this study with GenBank accession numbers for the ITS and LSU sequences (newly sequenced strains are indicated in boldface)

\begin{tabular}{|c|c|c|c|c|c|}
\hline \multirow[b]{2}{*}{ Species } & \multirow[b]{2}{*}{ Strain/herbarium } & \multirow[b]{2}{*}{ Location } & \multirow[b]{2}{*}{ Host } & \multicolumn{2}{|c|}{ GenBank accession nos. } \\
\hline & & & & ITS & LSU \\
\hline \multirow[t]{3}{*}{ Postia balsamea } & $\begin{array}{l}\text { CIEFAPcc 296/ } \\
\text { MR11974 }\end{array}$ & $\begin{array}{l}\text { Argentina, Neuquén, } \\
\text { Nahuel Huapi }\end{array}$ & Saxegothaea conspicua & JX090116 & - \\
\hline & $\begin{array}{l}\text { CIEFAPcc } 340 / \\
\text { MR12338 }\end{array}$ & $\begin{array}{l}\text { Argentina, Neuquén, } \\
\text { Nahuel Huapi }\end{array}$ & Nothofagus dombeyi & JX090108 & - \\
\hline & $\begin{array}{l}\text { CIEFAPcc 351/ } \\
\text { MR12413 }\end{array}$ & $\begin{array}{l}\text { Argentina, Chubut, } \\
\text { Los Alerces }\end{array}$ & Nothofagus dombeyi & JX090105 & JX090131 \\
\hline \multirow[t]{3}{*}{ (as Oligoporus) } & JB8609_9 & - & Malus sp. & JF950570 & - \\
\hline & $\mathrm{K}(\mathrm{M}) 31063$ & - & - & AY599566 & - \\
\hline & KEW35 & - & - & - & AF518640 \\
\hline \multirow[t]{5}{*}{ Postia caesia } & $\begin{array}{l}\text { CIEFAPcc 174/ } \\
\text { MR12276 }\end{array}$ & $\begin{array}{l}\text { Argentina, Chubut, } \\
\text { Los Alerces }\end{array}$ & Nothofagus antarctica & JX090109 & JX090129 \\
\hline & $\begin{array}{l}\text { CIEFAPcc 350/ } \\
\text { MR12421 }\end{array}$ & $\begin{array}{l}\text { Argentina, Chubut, } \\
\text { Los Alerces }\end{array}$ & Nothofagus dombeyi & JX090110 & JX090130 \\
\hline & $\mathrm{K}(\mathrm{M}) 31967$ & $\begin{array}{l}\text { UK, New Forest, } \\
\text { Hamps }\end{array}$ & Alnus & AY599567 & - \\
\hline & WD1974 & Japan, Kochi & - & - & AB569120 \\
\hline & WD1984 & Japan, Kochi & - & - & AB569119 \\
\hline \multirow[t]{2}{*}{ Postia carbophila } & $\begin{array}{l}\text { CIEFAPcc 162/ } \\
\text { MR10758 }\end{array}$ & $\begin{array}{l}\text { Argentina, Río } \\
\text { Negro, El Bolsón }\end{array}$ & Nothofagus sp. & JX090114 & JX090132 \\
\hline & $\begin{array}{l}\text { CIEFAPcc 257/ } \\
\text { MR12281 }\end{array}$ & $\begin{array}{l}\text { Argentina, Chubut, } \\
\text { Los Alerces }\end{array}$ & Nothofagus dombeyi & JX090115 & - \\
\hline \multirow[t]{2}{*}{ Postia dissecta } & $\begin{array}{l}\text { CIEFAPcc 328/ AG } \\
\text { s.n. }\end{array}$ & $\begin{array}{l}\text { Argentina, Chubut, } \\
\text { Golondrinas }\end{array}$ & Austrocedrus chilensis & JX090106 & JX090134 \\
\hline & $\begin{array}{l}\text { CIEFAPcc } 349 / \\
\text { MR12423 }\end{array}$ & $\begin{array}{l}\text { Argentina, Chubut, } \\
\text { Los Alerces }\end{array}$ & Nothofagus antarctica & JX090107 & JX090135 \\
\hline $\begin{array}{l}\text { Postia lactea (as } \\
\text { Oligoporus) }\end{array}$ & KEW55 & - & - & - & AY293205 \\
\hline \multirow[t]{2}{*}{ Postia leucomallela } & $\mathrm{K}(\mathrm{M}) 31064$ & UK, Surrey & - & AJ006663 & AF393072 \\
\hline & $\mathrm{K}(\mathrm{M}) 31057$ & UK, Surrey & - & AY599565 & - \\
\hline \multirow[t]{4}{*}{ Postia pelliculosa } & $\begin{array}{l}\text { CIEFAPcc 130/ } \\
\text { MR10592 }\end{array}$ & $\begin{array}{l}\text { Argentina, Chubut, } \\
\text { Los Alerces }\end{array}$ & Nothofagus dombeyi & JX090102 & JX090124 \\
\hline & $\begin{array}{l}\text { CIEFAPcc 221/ } \\
\text { MR10671 }\end{array}$ & $\begin{array}{l}\text { Argentina, Neuquén, } \\
\text { Lanín }\end{array}$ & Nothofagus alpina & JX090101 & JX090123 \\
\hline & CIEFAPcc 64/ DFP & $\begin{array}{l}\text { Australia, Victoria, } \\
\text { Cumberland Falls }\end{array}$ & Nothofagus sp. & JX090103 & JX090126 \\
\hline & $\begin{array}{l}\text { CIEFAPcc 75/ } \\
\text { PKB85159 }\end{array}$ & $\begin{array}{l}\text { New Zealand, } \\
\text { Southland, } \\
\text { Longwood St . For. }\end{array}$ & Nothofagus menziesii & JX090104 & JX090125 \\
\hline \multirow[t]{2}{*}{ Postia placenta } & FPRL 280 & - & - & EF524035 & - \\
\hline & JV0909/16 & Slovakia & - & JN592503 & - \\
\hline \multirow[t]{2}{*}{ Postia punctata } & $\begin{array}{l}\text { CIEFAPcc 40/ } \\
\text { MR11100 }\end{array}$ & $\begin{array}{l}\text { Argentina, Neuquén, } \\
\text { Lanín }\end{array}$ & Nothofagus dombeyi & JX090112 & JX090128 \\
\hline & $\begin{array}{l}\text { CIEFAPcc 344/ } \\
\text { MR12398 }\end{array}$ & $\begin{array}{l}\text { Chile, Región X, ca. } \\
\text { Santa Lucía }\end{array}$ & Nothofagus dombeyi & JX090111 & JX090127 \\
\hline \multirow[t]{2}{*}{$\begin{array}{l}\text { Postia rennyi (as } \\
\text { Oligoporus) }\end{array}$} & $\begin{array}{l}\text { CIEFAPcc 91/ } \\
\text { MR10497 }\end{array}$ & $\begin{array}{l}\text { Argentina, Chubut, } \\
\text { Futaleufú }\end{array}$ & Austrocedrus chilensis & JX090117 & - \\
\hline & KEW 57 & - & - & AY218416 & AF287876 \\
\hline Postia venata & $\begin{array}{l}\text { CIEFAPcc 346/ } \\
\text { MR12368 }\end{array}$ & $\begin{array}{l}\text { Chile, Región X, } \\
\text { Yelcho }\end{array}$ & Nothofagus dombeyi & JX090113 & JX090133 \\
\hline \multirow[t]{2}{*}{$\begin{array}{l}\text { Amyloporia } \\
\text { nothofaginea }\end{array}$} & $\begin{array}{l}\text { CIEFAPcc 196/ } \\
\text { SPG2802 }\end{array}$ & $\begin{array}{l}\text { Argentina, Chubut, } \\
\text { Los Alerces }\end{array}$ & Nothofagus dombeyi & JF713078 & - \\
\hline & $\begin{array}{l}\text { CIEFAPcc 304/ } \\
\text { MR12101 }\end{array}$ & $\begin{array}{l}\text { Argentina, Chubut, } \\
\text { Lago Puelo }\end{array}$ & Nothofagus dombeyi & JF713079 & - \\
\hline
\end{tabular}


TABLE I. Continued

\begin{tabular}{|c|c|c|c|c|c|}
\hline \multirow[b]{2}{*}{ Species } & \multirow[b]{2}{*}{ Strain/herbarium } & \multirow[b]{2}{*}{ Location } & \multirow[b]{2}{*}{ Host } & \multicolumn{2}{|c|}{ GenBank accession nos. } \\
\hline & & & & ITS & LSU \\
\hline \multirow{2}{*}{$\begin{array}{l}\text { Amyloporia xantha } \\
\text { (as Antrodia) }\end{array}$} & CBS200.91 & Turkey, Istanbul & Pinus sp. & AJ415569 & - \\
\hline & FCUG 1396 & Germany, Hamburg & - & - & AJ583430 \\
\hline Antrodia albida & CBS308.82 & USA, Madison & - & DQ491414 & - \\
\hline \multirow[t]{2}{*}{ Antrodia serialis } & CBS 306.82 & Germany, Reinhausen & Picea abies & DQ491417 & - \\
\hline & GEL 4465 & Germany & - & - & AJ406519 \\
\hline \multirow[t]{2}{*}{ Daedalea quercina } & HHB8735 & USA & - & FJ403214 & - \\
\hline & DAOM 142475 & - & - & & AF518613 \\
\hline Fibroporia gossypium & $\begin{array}{l}\text { CIEFAPcc 131/ } \\
\text { MR10569 }\end{array}$ & $\begin{array}{l}\text { Argentina, Chubut, } \\
\text { Futaleufú }\end{array}$ & Nothofagus pumilio & JF713075 & JX090142 \\
\hline Fibroporia vaillantii & $\begin{array}{l}\text { CIEFAPcc 261/ } \\
\text { MR11674 }\end{array}$ & $\begin{array}{l}\text { Argentina, Río Negro, } \\
\text { El Bolsón }\end{array}$ & Austrocedrus chilensis & JF713076 & - \\
\hline \multirow[t]{2}{*}{ Fomitopsis rosea } & ATCC 76767 & Turkey, Trabzon & - & DQ491410 & - \\
\hline & FP 104278-T & - & - & - & AY333809 \\
\hline \multirow[t]{2}{*}{ Fomitopsis pinicola } & UBC F16252/ & Canada & - & EF530947 & - \\
\hline & DAOM 189134 & - & - & - & AF287858 \\
\hline \multirow[t]{2}{*}{$\begin{array}{l}\text { Neolentiporus } \\
\quad \text { maculatissimus }\end{array}$} & $\begin{array}{r}\text { CIEFAPcc 92/ } \\
\text { BAFC } 31145\end{array}$ & $\begin{array}{l}\text { Argentina, Neuquén, } \\
\text { Nahuel Huapi }\end{array}$ & Nothofagus dombeyi & JX090121 & AF518632 \\
\hline & $\begin{array}{r}\text { CIEFAPcc 93/ } \\
\text { BAFC } 22451\end{array}$ & $\begin{array}{l}\text { Argentina, Neuquén, } \\
\text { Nahuel Huapi }\end{array}$ & Nothofagus dombeyi & JX090122 & - \\
\hline \multirow[t]{5}{*}{ Ryvardenia campyla } & $\begin{array}{l}\text { CIEFAPcc 124/ } \\
\text { MR10598 }\end{array}$ & $\begin{array}{l}\text { Argentina, Chubut, } \\
\text { Los Alerces }\end{array}$ & Nothofagus dombeyi & JQ677140 & - \\
\hline & $\begin{array}{l}\text { CIEFAPcc 197/ } \\
\text { MR10728 }\end{array}$ & $\begin{array}{l}\text { Argentina, Chubut, } \\
\text { Futaleufú }\end{array}$ & Nothofagus pumilio & JX090118 & JX090141 \\
\hline & $\begin{array}{l}\text { CIEFAPcc } 200 / \\
\text { MR10956 }\end{array}$ & $\begin{array}{l}\text { Chile, Región X, } \\
\text { Chiloé }\end{array}$ & - & JX090119 & JX090140 \\
\hline & NZFS2826 & New Zealand & Nothofagus fusca & JQ390051 & - \\
\hline & NZFS2828 & New Zealand & Nothofagus fusca & JQ390052 & - \\
\hline \multirow[t]{4}{*}{ Ryvardenia cretacea } & $\begin{array}{l}\text { CIEFAPcc 182/ } \\
\text { MR12329 }\end{array}$ & $\begin{array}{l}\text { Argentina, Neuquén, } \\
\text { Nahuel Huapi }\end{array}$ & Nothofagus dombeyi & JQ677142 & JX090137 \\
\hline & $\begin{array}{l}\text { CIEFAPcc } 348 / \\
\text { MR12429 }\end{array}$ & $\begin{array}{l}\text { Argentina, Neuquén, } \\
\text { Nahuel Huapi }\end{array}$ & Nothofagus dombeyi & JX090120 & JX090136 \\
\hline & $\begin{array}{r}\text { CIEFAPcc 97, ICMP } \\
11789 / \text { PKB87298 }\end{array}$ & $\begin{array}{l}\text { Australia, Tasmania, } \\
\text { Great Western Tiers }\end{array}$ & $\begin{array}{l}\text { Nothofagus } \\
\text { cunninghamii }\end{array}$ & JQ677138 & JX090139 \\
\hline & $\begin{array}{l}\text { CIEFAPcc 151, } \\
\text { CFMR } 6449\end{array}$ & Australia, Victoria & Eucalyptus regnans & JQ677141 & JX090138 \\
\hline
\end{tabular}

datasets: ITS and LSU (FIGS. 1, 2). The ITS sequence dataset included 45 taxa, 668 characters, with 383 of the characters being parsimony informative. Tree length (TL) 1512, consistency index (CI) and retention index (RI) were 0.52 and 0.773 respectively (FIG. 1). The LSU sequence dataset included 36 taxa, 881 characters and 170 parsimony informative. Tree length (TL) 552, CI of 0.53 and RI 0.74 (FIGS. 1, 2).

Overall, the taxa included in this research pertained to the "Antrodia clade" (Hibbett and Donoghue 2001) and were grouped into two subclades here named "Postia clade" and "dimitic taxa of Antrodia clade". Species formerly treated as Postia or Oligoporus were included in a monophyletic, strongly supported "Postia clade", in both types of phylogenetic analysis (MP and BI), and for both DNA datasets. Nevertheless, within the clade relationships between species were not well resolved because only isolates of $P$. pelliculosa formed a strong clade with $P$. punctata as its sister group. South American isolates of $P$. pelliculosa formed a separate branch from the Australasian isolates with a strong bootstrap value for each group (Figs. 1, 2). Strains of $P$. balsamea formed a group close to the $P$. pelliculosa-P. punctata clade but without bootstrap support. $P$. caesia also grouped with the latter species in ITS analysis but were placed at different phylogenetic positions based on MP and BI analysis of LSU DNA region. Relationships among those clades were not completely resolved. A similar result was obtained in the ITS analysis for $P$. venata and $P$. carbophila that grouped with $P$. caesia and $P$. leucomallela respectively, but those relationships were 


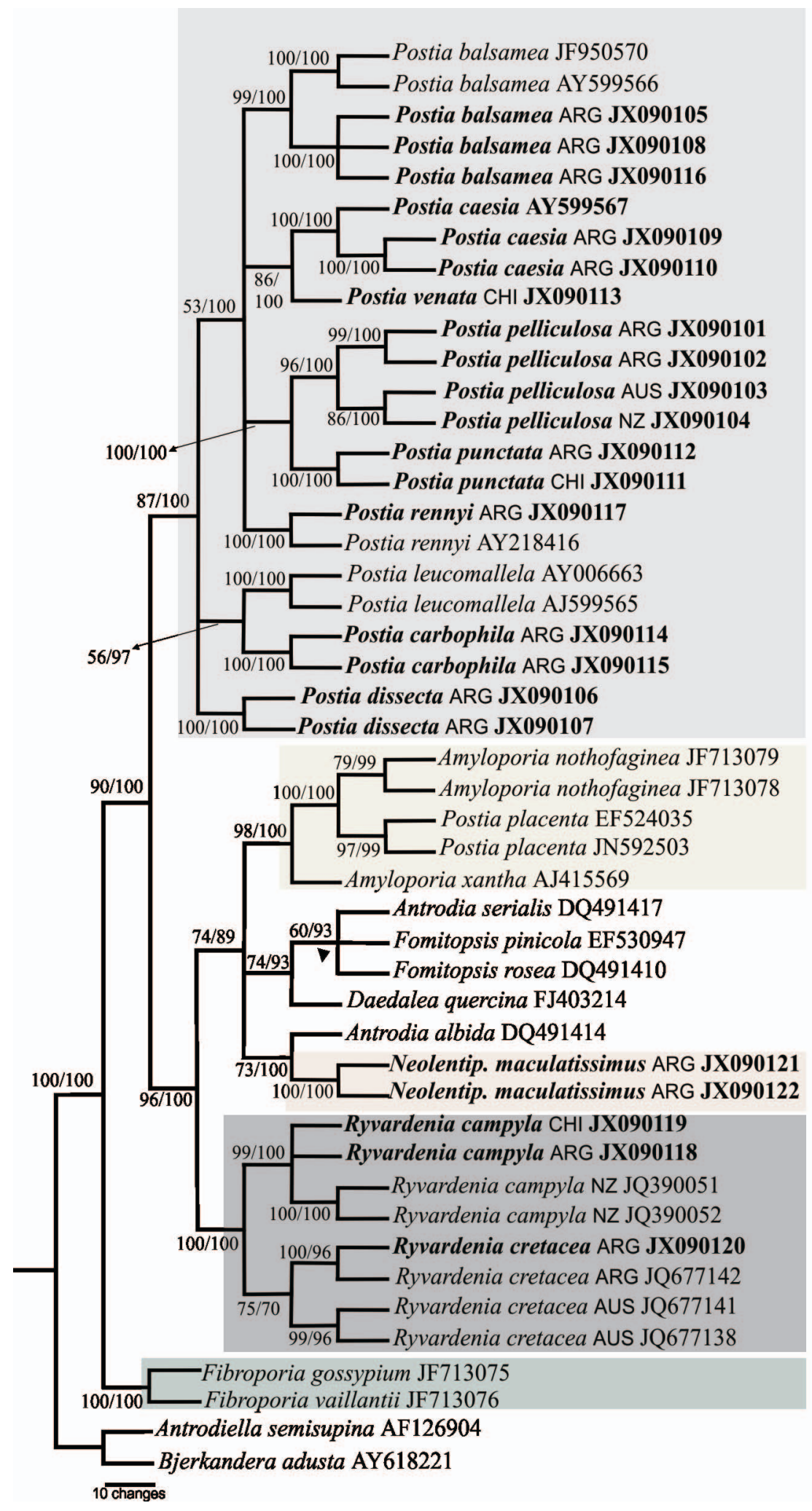

NB: normal MS: tetrapolar Mitism: 1 CrB: + Nuclei/ spore: 1

NB: heterocytic MS: bi/ tetrapolar Mitism: 2 CrB: -

Nuclei/ spore: 1

NB: Astatocoenocytic MS: bipolar Mitism: 2

CrB: -

Nuclei/spore: 2

NB: Astatocoenocytic

MS: bipolar

Mitism: 1 (context)

CrB: 2 (dissepiments)

Nuclei/ spore: 1

NB: normal

MS: tetrapolar

Mitism: 2

CrB: -

Nuclei/ spore: 1

FIG. 1. Phylogenetic relationships of Postia and Ryvardenia inferred with ITS parsimony (MP) and Bayesian (BI) analysis. Bootstrap values for internal nodes are given on the branches $(\mathrm{MP} / \mathrm{BI}))$. Support values $<50 \%$ are not indicated. Pointers indicate branches that collapse in the strict consensus tree. GenBank numbers in boldface indicate specimens for which sequencing data were generated. ARG: Argentina; AUS: Australia; CHI: Chile; NZ: New Zealand. NB: nuclear behavior; MS: mating system; Mitism: hyphal system (1) monomitic, (2) dimitic; CrB: metachromatism of generative hyphae (+) positive or (-) negative in cresyl blue. 


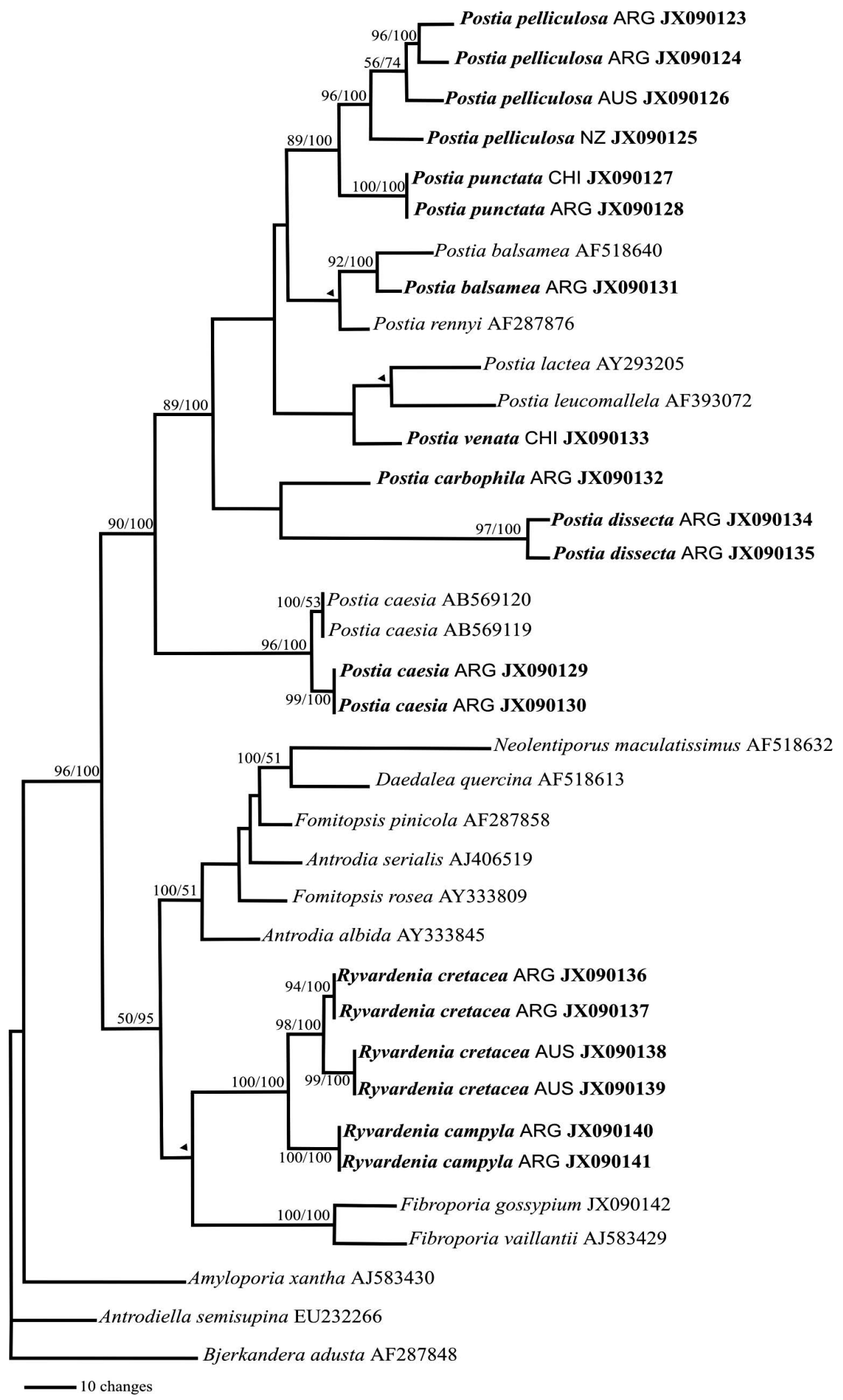

FIG. 2. Phylogenetic relationships of Postia and Ryvardenia inferred with LSU parsimony (MP) and Bayesian (BI) analysis. Bootstrap values for internal nodes are given on the branches (MP/BI). Support values $<50 \%$ are not indicated. Pointers indicate branches that collapse in the strict consensus tree. GenBank numbers in boldface indicate specimens for which sequencing data were generated in this study. ARG: Argentina; AUS: Australia; CHI: Chile; NZ: New Zealand. 
unresolved in the LSU analysis (FIGS. 1, 2). Unfortunately, no LSU sequences were obtained for $P$. rennyi from Patagonia.

Isolates of Ryvardenia formed a strong clade in both DNA dataset analyses, which was included in the group of "dimitic taxa of Antrodia clade". The latter as a whole was either strongly resolved in the ITS analyses and BI LSU analyses or weakly so in the MP LSU analyses. Ryvardenia, Neolentiporus, Fomitopsis, Daedalea, Antrodia and Amyloporia were included in the "dimitic taxa of Antrodia clade" in all analyses. Fibroporia presented an erratic disposition, being outside the clade in the ITS analysis and within it in the LSU analysis (FIGS. 1, 2).

The genus Ryvardenia formed a strongly monophyletic group supported in both datasets, which confirmed its description as an independent taxon. Its species, $R$. cretacea and $R$. campyla, were distinctly defined (FIGs. 1, 2). MP and BI analysis for both datasets grouped the isolates of $R$. cretacea from Chile and Argentina sister to those from Australia and New Zealand (FIGS. 1, 2). Isolates of P. placenta grouped in the same clade as Ryvardenia, Amyloporia, Neolentiporus, Daedalea, Fomitopsis and Antrodia, being closely related to Amyloporia nothofaginea as a sister species.

\section{DISCUSSION}

Sequences of two nuclear rDNA regions were used to infer the phylogenetic relationships of Postia and Ryvardenia species from Patagonia. Not all the isolates were analyzed in both datasets; Postia rennyi from Patagonia and Postia placenta only were included in the ITS analysis. The analyses identified two clades. "Postia" comprised species formerly treated as Postia or Oligoporus and included all Postia species from Patagonia as well as other taxa of the genus. Its morphological distinguishing feature is a monomitic hyphal system with metachromatic generative hyphae. Species with both thin- to thick-walled basidiospores grouped in this clade, suggesting that the thickness of the spore wall might not be essential in delimiting the genus, especially because no consistent substructure regarding spore thickness as a feature could be found. Only the two austral species, P. pelliculosa (spores very thick-walled) and P. punctata (spores slightly thickwalled) with ellipsoid to broadly ellipsoid basidiospores longer than $5 \mu \mathrm{m}$, formed a consistent phylogenetic group. They also formed a weakly supported group with other taxa with slightly thickened (i.e. P. balsamea) to thickened walls (i.e. $O$. rennyi).

Postia rennyi, the type species of Oligoporus, received variable bootstrap values according to the analyses. It occupied an undefined position in the ITS and LSU PAUP analyses. Therefore, and because no distinct features could be assigned to it, either molecular, morphological, sexual, cultural, or of nuclear behavior of the mycelium, and because no phylogenetic characterization was found, Oligoporus is here considered a synonym of Postia. Hattori et al. (2011) also found that $P$. rennyi clustered with species with thin-walled basidiospores in their analyses.

Other species from Patagonia did not follow any consistent relationship or pattern with other taxa in the genus. Species with thin-walled basidiospores formed two subgroups, one including species of the $P$. caesia species complex and the other subgroup including Postia type species P. lactea (Fr.) P. Karst. (= $P$. tephroleuca [Fr.] Jülich) and $P$. leucomallella (Murrill) Jülich. The austral $P$. venata, with thinwalled basidiospores, merged with either $P$. caesia species complex or P. tephroleuca according to ITS or LSU analyses respectively. The austral $P$. carbophila, with thin-walled basidiospores, was positioned unresolved either with $P$. leucomallela or with $P$. dissecta (ITS and LSU phylogenies respectively).

Species well known and distributed in the northern hemisphere but whose presence was unknown until recently from the southern continents (Rajchenberg 2006) grouped well with specimens from Patagonia. This was the case for $P$. balsamea, $P$. rennyi and $P$. caesia. For the latter case a more detailed study is needed to verify their identity because specimens from Patagonia formed a distinct subclade separated from taxa/specimens from the northern hemisphere, where they form a species complex (Yao et al. 2005). The endemic $P$. carbophila was related to Postia placenta when originally described on the basis of basidiome coloration, its resupinate habit, spore morphology and the presence of a resinous matter between the hyphae (Rajchenberg 1995). Our study showed that it is distantly related to that species, being perfectly nested within Postia. For the placement of $P$. placenta see below.

The other clade identified by the analyses comprised the "dimitic species of the Antrodia clade", which included the two Ryvardenia species, this genus being well supported as monophyletic in all analyses. This is the first time the genus Ryvardenia was included in a phylogenetic study. The results showed it to be within the "dimitic taxa of Antrodia clade" and distant from Postia, in which species of Ryvardenia had been included. Phylogenetic analyses consistently dismissed a close relationship between Ryvardenia and Postia, thereby supporting the morphological and biological features that led to its creation (Rajchenberg 1994, FIGS. 1, 2). Both species in the genus were very well supported as a clade and well distinguished at the species level. 
The biological features presented by Ryvardenia also are present in Neolentiporus maculatissimus (Lloyd) Rajchenb. (Rajchenberg 1995, 2006). This austral species is distinguished by cylindrical, binucleated, thin-walled basidiospores, bipolar mating, astatocoenocity and by a hyphal system with irregularly thickened hyphae, which is lacking in Ryvardenia. The species also was included in this study; it was not closely related to Ryvardenia but instead to the bulk of genera Antrodia, Daedalea and Fomitopsis (as already shown by Hibbett and Donoghue [2001]), which display cylindrical to ellipsoid basidiospores that are generally uninucleate (but binucleate in $A$. albida, A. heteromorpha [Fr.] Donk and A. salicina [Bres.] H. Jahn), a normal nuclear behavior and homothallism or bipolar mating.

Postia placenta, as explained above, was included in this study because the Patagonian P. carbophila was considered a related species when described (Rajchenberg 1995). It was long considered a species of Postia but was segregated into a genus of its own as Rhodonia placenta Niemelä, K.H. Larss. \& Schigel based on phylogenetic studies (Niemelä et al. 2005, Schigel et al. unpubl). Boidin et al. (1998), Kim et al. (2001) and Binder et al. (2005) had already shown that this taxon is distinct from the bulk of species in Postia. More notable is the fact that this species had been distinguished long before by displaying a heterocytic nuclear behavior (David 1988), a feature unknown in Postia (David 1980). Its mating system is tetrapolar according to David (1988) but Nobles (1943) stated it to be bipolar; confirmation of this feature is needed. Our study, based on ITS and LSU analyses, found a potential association of $P$. placenta with taxa in Amyloporia, a genus with dimitic species that also displays a heterocytic nuclear behavior and either bipolar or tetrapolar mating (Rajchenberg et al. 2011, Rajchenberg 2011). A strong association was found between $P$. placenta and the recently described taxon Amyloporia nothofaginea Rajchenb. \& Gorjón which nevertheless is easily distinguished from $P$. placenta by its hymenial coloration (white-cream) and a dimitic hyphal system (but cf. Niemelä et al. [2005] who describe hyphae that become thickened upon maturation, giving the structure a dimitic appearance). The relationship of $P$. placenta to Amyloporia needs further research. Kim et al. (2001) and Binder et al. (2005) also reported an association between $P$. placenta and Amyloporia xantha (Fr.) Bondartsev \& Singer, and Garcia-Sandoval et al. (2011) with Amyloporia carbonica (Overh.) Vampola \& Pouzar. When we tested this relationship after incorporating more Amyloporia taxa (i.e. A. carbonica [Overh.] Vampola \& Pouzar, A. sitchensis [D.V. Baxter] Vampola \& Pouzar, A. stratosa [J.E. Wright \& J.R.
Deschamps] Rajchenb., Gorjón \& Pildain and $A$. sordida [Ryvarden \& Gilb.] Vampola \& Pouzar), it remained unchanged (unpubl).

Fibroporia taxa relationships remained rather unclear in this study; they were either associated with the "dimitic taxa of Antrodia clade" or occurred as a separate clade. This supports results in which the genus formed a separate clade within Antrodia s.l. (Rajchenberg et al. 2011) or occupied a distant position (Kim et al. 2001).

Our study also revealed a strong separation between specimens of $P$. pelliculosa and $R$. cretacea from either side of the Pacific (i.e. SE Australia/New Zealand and S Argentina/S Chile), suggesting they could be considered different species on phylogenetic grounds. Nevertheless, Rajchenberg (1994) and Rajchenberg and Greslebin (1995) reported biological compatibility between strains from both areas through dikaryotic $\times$ monosporous or through monosporous $\times$ monosporous confrontation tests. For this reason, as well as the lack of morphological differences, we have deferred describing new taxa from the $R$. cretacea species complex (Rajchenberg and Pildain 2012). However future work may reveal more substantial molecular differences not reflected by morphology and compatibility, as has been found for many other cases (Cai et al. 2011). For R. campyla, the Argentinean and Chilean strains formed a polytomy vis à vis the two New Zealand strains (ITS analyses, no LSU data was available). In this case it is possible that the unresolved relationship is due to the fact that both New Zealand strains came from a similar place, although this is not completely evident from the available data. More strains thus are needed to verify whether a biogeographical isolation between populations of this species exists, as shown for $P$. pelliculosa and $R$. cretacea.

A better understanding of the phylogenetic relationships within the "Postia clade" requires the inclusion of a larger number of strains of certain taxa as well as the incorporation of additional genes. The number of parsimony informative characters within the partial LSU rDNA sequence was fewer than for ITS rDNA sequences; thus it is not surprising that phylogenetic inferences based on analyses of the LSU represent the relationships of higher nodes, and most of relationships below this level could be analyzed based on ITS. However, our phylogenetic analyses of ITS and LSU rDNA sequences for "Postia clade" shows that clades representing species were strongly supported and that the majority of relationships above this level are unresolved (FIGS. 1, 2). More characters from unlinked loci and protein-coding genes might help resolve these relationships. Our interest is the need to get a clearer understanding of 
the relative importance of spore-wall thickness in the phylogenetic definition of the genus. In this study we were able to couple morphological and biological features of certain genera with molecular-based phylogenies highlighting their importance, offering a more comprehensive view of evolution within each group of organisms and offering a coherent picture of each clade within the Polyporales. Nevertheless, further in-depth studies are needed within the genera and among other genera in the "dimitic taxa of Antrodia clade" to understand infrageneric relationships.

The inclusion of taxa from the southern hemisphere, especially from southern South America because of the particular origin of its biota (Sanmartín and Ronquist 2004), helps put into perspective phylogenetic studies in which the southern hemisphere mycota is either not included or generally outnumbered by northern hemisphere taxa.

\section{ACKNOWLEDGMENTS}

We thank curators of herbaria and culture collections for materials provided for this research. G. Gates and D. Ratkowsky (Hobart, Tasmania) kindly reviewed the manuscript before submission and made valuable comments. Two anonymous reviewers provided constructive criticism to improve the text. We acknowledge the Heads of Parques Nacionales Agency (APN) for letting us collect specimens in protected areas under their keeping. Authors are researchers of the Nationall Research Council of Argentina (CONICET), which supported this research through grant PIP 80101000.

\section{LITERATURE CITED}

Bernicchia A. 2005. Polyporaceae s.l.. Alassio, Italy: Ed Candusso. 808 p.

, Pérez Gorjón S, Vampola P, Ryvarden L, Prodi A. 2012. A phylogenetic analysis of Antrodia s.l. based on nrDNA ITS sequences, with emphasis on rhizomorphic European species. Mycol Prog 11:93-100, doi:10.1007/ s11557-010-0732-z

Binder M, Hibbett SH, Larsson KH, Larsson E, Langer E, Langer G. 2005. The phylogenetic distribution of resupinate forms across the major clades of mushroom-forming fungi (Homobasidiomycetes). Syst Biodivers 3:113-157, doi:10.1017/S1477200005001623

Boidin J. 1971. Nuclear behavior in the mycelium and the evolution of Basidiomycetes. In: Petersen RH, ed. Evolution in the higher Basidiomycetes. Knoxville: Univ. Tennessee Press. p 129-148.

— Mugnier J, Canales R. 1998. Taxonomie moleculaire des Aphyllophorales. Mycotaxon 66:445-491.

Buchanan PK, Hood IA. 1992. New species and new records of Aphyllophorales (Basidiomycetes) from New Zealand. NZ J Bot 30:95-112, doi:10.1080/ 0028825X.1992.10412888
Cai L, Giraud T, Zhang N, Begerow D, Cai G, Shivas RG. 2011. The evolution of species concepts and species recognition criteria in plant pathogenic fungi. Fungal Divers 50:121-133, doi:10.1007/s13225-011-0127-8

Cunningham GH. 1965. Polyporaceae of New Zealand. NZ DSIR Bull 164:1-304.

Dai YC. 2011. Polypore diversity in China with an annotated checklist of Chinese polypores. Mycoscience 35:49-80.

David A. 1980. Étude du genre Tyromyces sensu lato: répartition dans les genres Leptoporus, Spongiporus et Tyromyces sensu stricto. Bull Soc Linn Lyon 49:6-56.

- 1988. Bedeutung des Studiums des Kernverhaltens in der Systematik der Polyporaceae. In: Wolkinger F, ed. Internationales Aphyllophorales-Symposium Eisenstadt 1982. Graz: Austrian Acad Sci. p 23-28.

Donk MA. 1960. The generic names proposed for Polyporaceae. Persoonia 1:173-302.

Douanla-Meli C. 2007. Fungi of Cameroon. Bibliotheca Mycol B. 202:1-410. Berlin: J. Cramer. 410 p.

Erkkilä R, Niemelä T. 1986. Polypores in the parks and forests of the city of Helsinki. Karstenia 26:1-40.

Garcia-Sandoval R, Wang Z, Binder M, Hibbett DS. 2011. Molecular phylogenetics of the Gloeophyllales and relative ages of clades of Agaricomycotina producing a brown rot. Mycologia 103:510-524, doi:10.3852/10-209

Gilbertson RL, Ryvarden L. 1987. North American polypores. Vol. 2. Megasporoporia- Wrightoporia. Oslo: Fungiflora. p 434-885.

Hall TA. 1999. BioEdit: a user-friendly biological sequence alignment editor and analysis program for Windows 95/98/NT. Nucleic Acids Symp Ser 41:95-98.

Hattori T, Sotome K, Ota Y, Thi BK, Lee SS, Salleh B. 2011. Postia stellifera sp. nov., a stipitate and terrestrial polypore from Malaysia. Mycotaxon 114:151-161, doi:10.5248/114.151

Hibbett DS, Donoghue MJ. 2001. Analysis of character correlations among wood decay mechanisms, mating systems and substrate ranges in homobasidiomycetes. Syst Biol 50:215-242, doi:10.1080/10635150151125879

Holmgren PK, Holmgren NH, Barnett LC. 1990. Index herbariorum I: the herbaria of the world. New York: New York Botanical Garden. 693 p.

Kim KM, Lee JS, Jung HS. 2007. Fomitopsis incarnatus sp. nov. based on generic evaluation of Fomitopsis and Rhodofomes. Mycologia 99:833-841, doi:10.3852/mycologia.99.6.833

— of Antrodia and related genera based on ribosomal RNA internal transcribed space sequences. J Microbiol Biotechnol 11:475-481.

— - , Ko KS, Jung HS. 2003. Phylogenetic analysis of Antrodia and related taxa based on partial mitochondrial SSU rDNA sequences. Antonie van Leeuwenhoek 83:81-88, doi:10.1023/A:1022993703799

, Yoon YG, Jung HS. 2005. Evaluation of the monophyly of Fomitopsis using parsimony and MCMC methods. Mycologia 97:812-822, doi:10.3852/mycologia. 97.4.812

Larsen MJ, Lombard FF. 1986. New combinations in the genus Postia Fr. (Polyporaceae). Mycotaxon 26:271273. 
Lindner DL, Banik MT. 2008. Molecular phylogeny of Laetiporus and other brown-rot polypore genera in North America. Mycologia 100:417-430, doi:10.3852/ 07-124R2

_, Ryvarden L, Baroni TJ. 2011. A new species of Daedalea (Basidiomycota) and a synopsis of core species in Daedalea sensu stricto. N Am Fungi 6:1-12.

Lowe JL. 1975. Polyporaceae of North America, the genus Tyromyces. Mycotaxon 2:1-82.

Niemelä T, Kinnunen J, Larsson K-H, Schigel DS, Larsson E. 2005. Genus revisions and new combinations of some North European polypores. Karstenia 45:75-80.

Nobles MK. 1943. A contribution toward a clarification of the Trametes serialis complex. Can J Res C 21:211-218, doi: $10.1139 /$ cjr43c-018

Núñez M, Ryvarden L. 2001. East Asian polypores. Vol. 2. Polyporaceae s.l. Synop Fungorum vol 14. 170-522, Oslo: Fungiflora.

Posada D, Crandall KA. 1998. Modeltest: testing the model of DNA substitution. Bioinformatics 14:817-818, doi:10.1093/bioinformatics/14.9.817

Rajchenberg M. 1994. A taxonomic study of the subantarctic Piptoporus (Polyporaceae, Basidiomycetes) I. Nord J Bot 14:435-449, doi:10.1111/j.1756-1051.1994.tb00629.x

—_- 1995. A taxonomic study of the subantarctic Piptoporus (Polyporaceae, Basidiomycetes) II. Nord J Bot 15:105-119, doi:10.1111/j.1756-1051.1995.tb00127.x

. 2006. Polypores (Basidiomycetes) from the Patagonian Andes forests of Argentina. Bibliotheca Mycologica Band 201. Stutgart: J. Cramer Verlag. 300 p.

- 2011. Nuclear behavior of the mycelium and the phylogeny of Polypores (Polyporales Basidiomycota). Mycologia 103:677-702, doi:10.3852/10-310

, Greslebin A. 1995. Cultural characters, compatibility tests and taxonomic remarks of selected polypores of the Patagonian Andes forests of Argentina. Mycotaxon 56:325-346.

—_, Pérez Gorjón S, Pildain MB. 2011. The phylogenetic disposition of Antrodia s.l. from Patagonia, Argentina. Aust Syst Bot 24:111-120, doi:10.1071/SB11003

—_, Pildain MB. 2012. Molecular studies reveal a speciation process within Ryvardenia cretacea (Polyporales, Basidiomycota). Kurtziana 37:7-13.

Renvall P. 1992. Basidiomycetes at the timberline in Lapland 4. Postia lateritia n. sp. and its rust-colored relatives. Karstenia 32:43-60.

Ronquist F, Huelsenbeck JP. 2003. MrBayes 3: Bayesian phylogenetic inference under mixed models. Bioinfor- matics 19:1572-1574, doi:10.1093/bioinformatics/ btg 180

Ryvarden L. 1991. Genera of Polypores. Nomenclature and Taxonomy. Synopsis Fungorum 5. Oslo: Fungiflora. $363 \mathrm{p}$.

— Gilbertson RL. 1993. European Polypores 1. Oslo: Fungiflora. p 1-393.

- 1 1994. European Polypores 2. Oslo: Fungiflora. p 394-743.

— Johansen I. 1980. A preliminary polypore flora of east Africa. Oslo: Fungiflora. 636 p.

Sanmartín I, Ronquist F. 2004. Southern hemisphere biogeography inferred by event-based models: plant versus animal patterns. Syst Biol 53:216-243, doi:10.1080/10635150490423430

Swofford DL. 2000. PAUP* 4.0: phylogenetic analysis using parsimony (*and other methods). Sunderland Massachusetts: Sinauer Associates.

Tamura K, Dudley J, Nei M, Kumar S. 2007. MEGA4: molecular evolutionary genetics analysis (MEGA) software. Version 4.0. Mol Biol Evol 24:1596-1599.

Vilgalys R, Hester M. 1990. Rapid genetic identification and mapping of enzymatically amplified ribosomal DNA from several Cryptococcus species. J Bacteriol 172:42384246.

Walker J. 1996. An opinion on the validity of the generic name Postia Fries 1874 (Eumycota: Aphyllophorales). Australas Mycol Soc Newslett 15:23-26.

White TJ, Bruns T, Lee S, Taylor J. 1990. Amplification and direct sequencing of fungal ribosomal RNA genes for phylogenetics. In: Innis MA, Gelfand DH, Sninsky JJ, White TJ, eds. PCR protocols. San Diego, California: Academic Press. p 315-322.

Wu SH, Yu ZH, Dai YC, Chen CT, Su CH, Chen LC, Hsu WC, Hwang GY. 2004. Taiwanofungus, a polypore new genus. Fungal Sci 19:109-116.

Yao YJ, Pegler DN, Chase MW. 1999. Application of ITS (nrDNA) sequences in the phylogenetic study of Tyromyces s.l. Mycol Res 103:219-229, doi:10.1017/ S0953756298007138

- - - 2005. Molecular variation in the Postia caesia complex. FEMS Microbiol Lett 242:109116, doi:10.1016/j.femsle.2004.10.046

Yu ZH, Wu SH, Wang DM, Chen CT. 2010. Phylogenetic relationships of Antrodia species and related taxa based on analyses of nuclear large subunit ribosomal DNA sequences. Bot Stud 51:53-60. 